\title{
Візуалізація суспільного життя окупованої території Луганської області у друкованих засобах масової інформації
}

\author{
Котеленець К. М., Луганський національний університет імені Тараса Шевченка
}

Розглядається суспільне життя окупованої території Луганської області у друкованих засобах масової інформації. Зазначена методологія дослідження, розписані методи та методологія дослідження друкованих засобів масової інформації, складена вибірка. Наводяться деякі результати контент-аналізу газет, які друкувались протягом року у трьох населених пунктах так званої Луганської народної республіки, а саме: Луганську, Стаханові (Кадіївці) та Антрациті. Проаналізовані світлини обраних газет, які відображають суспільні процеси на окупованій території Луганської області. Саме світлини надають змогу зробити висновок, що газети мають інформаційний напрям контенту, що інформація, яка в них надається, найчастіше має побутовий або економічний характер, а також, що концентрується увага на ситуативних заходах. Доведено, що світлини мають розбіжності між розміром та контекстом, тобто незначна кількість світлин компенсується їх великим розміром, особливо політичних лідерів Російської Федерації та самої так званої Луганської народної республіки. Робиться висновок, що фотографії на шпальтах газет так званої ЛНР найчастіше відображають інфраструктурні, побутові проблеми та проблеми благоустрою, а також концентрують увагу на культурному та розважальному житті так званої Луганської народної республіки.

Ключові слова: контент-аналіз; окупована територія; суспільне життя; відображення суспільного життя; друковані засоби масової інформації; мас-медіа; газета; окупована територія; фотографія; візуалізація

\section{Visualization of the social life of the occupied territory of the Lugansk region in the print media}

\section{Kotelenets K. M., Lugansk Taras Shevchenko National University}

The article deals with the public life of the occupied territory of the Lugansk region in printed mass media. The article presents some results of the content analysis of the print media of the occupied tourists of the Lugansk region. They are concentrating on analyzing photos that were printed during the year in the newspapers of the so-called Luhansk People's Republic. This methodology of research, painted methods and methodology of the research of printed mass media, a sample is drawn up. The article presents some results of the content analysis of newspapers that were printed during the year in three cities of the so-called Luhansk People's Republic, namely Lugansk, Stakhanov (Kadyivka) and Antratsyt. The article analyzes the literature on the topic of the study, systematic theoretical foundations of the functioning of mass media, in particular printed mass media. Mechanisms of influence of mass media on social consciousness are considered. The focus is on the current situation in the East of Ukraine. Examples are examples of manipulation and propaganda through the mass media that have an impact on the consciousness of the society, the data of the security services of Ukraine on the use of innovative technologies by the Russian Federation for the purpose of implementing their actions in the territory of the occupied Donbas are given. The photos of selected newspapers that reflect the social processes in the occupied territory of the Lugansk region are analyzed. It is the photos that make it possible to conclude that newspapers have an information content direction that the information they provide most often has a domestic or economic nature, and that focus is on situational events.

It is proved that the photos have disagreements between size and context, that is, a small number of photos are compensated for by their large size, especially political leaders of the Russian Federation and the so-called Lugansk People's Republic. It is concluded that the photographs on the pages of the so-called LNR newspapers most often reflect the infrastructure, everyday problems and problems of improvement, and also focus on the cultural and entertaining life of the so-called Lugansk People's Republic.

Keywords: content analysis; occupied territory; public life; reflection of public life; printed mass media; mass media; newspaper; occupied territory; photography; visualization

\section{Визуализация общественной жизни оккупированной территории Луганской области в печатных средствах массовой информации}

\section{Котеленец К. М., Луганский национальный университет имени Тараса Шевченко}

Рассматривается общественная жизнь оккупированной территории Луганской области в средствах массовой информации. Указаны методология исследования, расписаны методы и методология исследования печатных СМИ, составлена выборка. Приводятся некоторые результаты контент-анализа газет, которые печатались в течение года в трех городах так называемой Луганской народной республики, а именно: Луганске, Стаханове (Кадиевке) и Антраците. Проанализированы фотографии избранных газет, отражающих общественные процессы на оккупированной территории Луганской области. Именно фотографии дают возможность сделать вывод, что газеты имеют информационное направление контента, информация, которая в них предоставляется, чаще всего имеет бытовой или экономический характер, а также, что концентрируется внимание на ситуативных мероприятиях. 
Доказано, что фотографии имеют разногласия между размером и контекстом, то есть незначительное количество фотографий компенсируется их большим размером, особенно политических лидеров Российской Федерации и самой так называемой Луганской народной республики. Делается вывод, что фотографии на страницах газет так называемой ЛНР чаще всего отражают инфраструктурные, бытовые проблемы и проблемы благоустройства, а также концентрируют внимание на культурной и развлекательной жизни так называемой Луганской народной республики.

Ключевые слова: контент-анализ; оккупированная территория; общественная жизнь; отражение общественной жизни; печатные средства массовой информации; масс-медиа; газета; оккупированная территория; фотография; визуализация

\section{Постановка проблеми.}

$\mathrm{B}$ умовах гібридної війни, яка розгорнулась 3 весни 2014 року на території Луганської області, засоби масової інформації виконували ідеологічну та пропагандистську функції. Щоб закріпити свої позиції «нова» влада окупованої частини області, так званої ЛНР (Луганська Народна Республіка), використовувала регіональні мас-медіа як інструмент висвітлення негативних рис української влади та, навпаки, позитивні риси та плани на майбутнє «новоспеченої республіки». Особливе місце в інформаційній війні зайняли друковані 3МI. На ринку виникли як нові газети, так і залишились деякі, що функціонували й раніше, але змінили свою ідеологію. У таких умовах деяка територія Луганської області опинилась в інформаційній війні. Таким чином, виникла нагальна потреба у вивченні суспільного життя окупованих територій за допомогою друкованих 3МІ. Проте публікацій щодо контент-аналізу ЗМІ ЛНР вкрай мало, а про дослідження друкованих ЗМІ окупованої території взагалі відсутні.

\section{Аналіз досліджень і публікацій.}

У сучасному соціогуманітарному знанні існує значна кількість фундаментальних праць 3 дослідження функціонування засобів масової інформації, їх впливу на суспільство та канали розповсюдження інформації. Окремі роботи присвячені розробці технологій лобіювання та пропаганди за допомогою мас-медіа. Саме аналіз наукової літератури показав, що достатньо багато наукових робіт присвячено дослідженню різних аспектів засобів масової інформації. Одним із перших соціологічних осмислень засобів масової інформації було дослідження преси М. Вебером [8], який під ЗМІ розумів інструмент акцентованого вираження інтересів різних соціальних груп і формування людини як члена суспільства. Проте багато соціологів зупинялись на ролі засобів масової комунікації у формуванні суспільної свідомості чи суспільного інформаційного простору. Саме ці аспекти формування засобів масової інформації можна знайти у роботах: Т. Адорно [1], 3. Баумана [3], П. Бергера [4], Ж. Бодрійяра [5], П. Бурд’є [6], I. Валерстайна [7], Б. Грушина [9], Р. Мертона [15], Г. Почепцова [16], О. Тофлера [18], Ю. Хабермаса [20] та ін.

Наразі сучасні дослідники та науковці акцентують свою увагу на вивчені засобів масової ін- формації у інформаційному інтернет-просторі. Наприклад, у дослідженнях прихильників теорії інформаційного суспільства Д. Батлера [2], М. Кастельса [11], Г. Маклюена [14] та ін. засоби масової інформації тлумачаться як сукупність методів, ресурсів, технологій, комунікативних стратегій створення, поширення та сприйняття інформації крізь призму динаміки інформаційного середовища. Проте, не зважаючи на різнобарвність наукової літератури досліджень 3МI, роботи про масмедіа під час гібридної війни знайти вкрай важко, а публікації щодо досліджень друкованих ЗМІ на території новоутворених «республік» - ще важче, а дослідження візуалізацій чи світлин у цих виданнях - майже неможливо. Тому дослідження $\epsilon$ актуальним для сучасної науки.

Метою дослідження $є$ вивчення суспільного життя через аналіз світлин у друкованих засобах масової інформації на окупованій території Луганської області.

\section{Виклад основного матеріалу.}

Інформація завжди впливала на всі сфери життєдіяльності суспільства. Вона має дуже широкий вплив на погляди, настрої і на формування громадської свідомості. Найбільше на формування і поширення громадської думки впливають засоби масової інформації - сукупність сучасних каналів зв'язку (преса, радіо, телебачення, Інтернет тощо), за допомогою яких поширюється різноманітна інформація у суспільстві. У наш час засоби масової інформації стали головним інструментом для поширення повідомлень, що впливають на суспільну свідомість. А. Моль написав: «Вони фактично контролюють всю нашу культуру, пропускаючи iii через свої фільтри, виділяють окремі елементи iз загальної маси культурних явищ і надають їм особливої уваги, підвищують цінність однієї ідеї, знецінюють іншу, поляризують таким чином все поле культури. Те, що не потрапило в канали масової комунікації, в наш час майже не впливає на розвиток суспільства» [10].

У науковій літературі можна зустріти термін «маніпуляція свідомістю» - це вплив засобів масової інформації на суспільну думку. Маніпулюванням $€$ приховане керування свідомістю та поведінкою членів суспільства 3 метою схилити діяти всупереч власним інтересам. Найчастіше в основі маніпулювання лежить обман і брехня [12]. 
Реальність, що створюється засобами масової інформації, перетворює реальну картину світу, що і є маніпулюванням. Мас-медіа мають монополію на інформацію i тому визначають пріоритети подій, які треба висвітлювати. Тому кожну годину у світі трапляється величезна кількість подій, але для нас виводиться тільки та частина, яку засоби масової комунікації вводять у сферу уваги [12]. Також маніпуляція мас-медіа полягає в необхідності розтлумачувати i коментувати новини чи факти [12]. ЗМІ впливають на суспільну свідомість через усі статево-вікові групи населення, що веде за собою заміну свідомості через повторення певної інформації, а також зменшення особистого простору людини, в якому він міг би перебувати без впливу реклами або іншої інформації цільового призначення. У 21 столітті засоби масової інформації стали настільки впливовими і значущими, що створюють єдиний інформаційний простір, що консолідує думки, почуття, бажання людей в єдину думку. Вони стають початковим джерелом інформації, насамперед, про навколишній світ. 3береження культурних традицій стає першочерговим завданням, тому мас-медіа можуть відіграти вирішальну роль у підсиленні консолідації суспільства та збереженні його національно-культурної самобутності. В сучасному українському суспільстві $є$ посилення інформаційних потоків зарубіжної культури, яка не притаманна українським ідеалам, духовності, цінностям. Це впливає не лише на становлення національної самоідентифікації населення, але й на громадську активність, громадяни починають сприймати себе частиною чужого культурного простору [17]. Вміло маніпулюючи громадською свідомістю за допомогою різних засобів масової інформації, можна не тільки створювати і направляти розвиток культури, свідомості й поведінки суспільства, а й прищеплювати певну роль кожного соціального класу і навіть кожній людині окремо. Одним із негативних впливів 3МІ на людську свідомість є пропаганда. В якомусь сенсі це дезінформація, тобто подана інформація виявляється брехнею. Дезінформація подається 3 різних джерел і западає в підсвідомість людині. Це дуже ефективний метод впливати на свідомість суспільства і водночас дуже жорстокий [12].

Доведено, що пропагандистську складову можна спостерігати у так званій «гібридній війні», яку Росія розпочала проти України. У квітні 2014 року Україна зазнала прямої агресії з боку Росії. I зараз всі ці події називають «гібридною війною». Обгрунтовано, що в інформаційній агресії проти України були застосовані методи психотропної дії, а саме використання забороненої технології «25го кадру». «У Службі безпеки України заявили про те, що мають докази використання російськими телеканалами технології «25-го кадру» для інформаційно-психологічного впливу на глядачів. Начальник прес-служби СБУ Марина Остапенко продемонструвала журналістам відеофрагмент випуску новин на каналі «Росія-24», в якому використовується маніпулятивна технологія. Так, протягом усього випуску про події в Одесі 2 травня в куті екрана з'являються малопомітні написи: «підпал», «Правий сектор», «людей убивають бандерівці», «нацгвардія - вбивці». Також вдалося встановити, що російські ЗМІ використовують ще інші методи впливу на глядачів: поширюють напівправду, показують деталізовані сцени вбивств і насильства та таким чином намагаються емоційно впливати на глядача» [19]. У конфлікті на Сході України поширена технологія «мемів», можна сказати що це своєрідна «мова» нового покоління, яка здатна однією маленькою «картинкою» або словом замінити великі тексти. Меми можуть мати патріотичне спрямування, як «кіборги», «укропи», або як «ватники», «сепари» та інші. Ще однією технологією є «фотожаби», які представляють собою шарж, тобто гумористичний колаж, який робиться 3 будь-якої фотографії, ці «фотожаби» носять переважно карикатурний характер i висміюють в першу чергу політиків, акторів, спортсменів та ін.

Таким чином, засоби масової інформації, формуючи суспільну думку, мають дуже великий вплив на масову свідомість. Тому є доцільним дослідити одну зі складових впливів на свідомість, а саме візуалізовані технології у друкованих ЗМІ тимчасово окупованих територій.

Врахувавши усі складності та ризики був складений план дослідження. Проаналізувавши зміст кожної з вибраних газет, дійшли висновку, що серед представлених газет найновиннішими виявились 4 газети. I тому для дослідження було обрано 2 газети з Луганська, 1 - зі Стаханова (Кадіївки) та 1 - 3 Антрациту. Таким чином, аналізувались: «Экспресс Новости» (Експрес новини) та «XXI Век» (21 століття) 3 центру ЛНР (Луганськ) та дві «Козачий вестник» (Козачій вісник), яка виходить у м. Стаханов (Кадіївка), та «Антрацитовский вестник» (Антрацитівський вісник), яка виходить у м. Антрацит, що є периферією «республіки». Ці газети регулярно виходили протягом року на території так званої Луганської Народної Республіки, а саме 31 жовтня 2016 року по 1 жовтня 2017 року. Протягом року утворювалася вибірка контент-аналізу: з 192 номерів обрано 69.

У ході контент-аналізу виявлено, що на території «новоспечених республік» преса друкується виключно російською мовою, тобто в усіх газетах ЛНР не публікуються статті українською мовою, проте, інколи з'являються українські цитати, які написані російськими буквами, наприклад «СВИТЛЕ МАЙБУТНЕ», «СТАЛО ЖЫТЫ 
КРАЩЕ» тощо. Аналіз візуалізованих матеріалів - протягом року в досліджуваних газетах опубліковано 1224 світлини. Аналізуючи контекст фотографій, які друкуються на шпальтах газет ЛНР, дійшли висновку, що велика кількість фотографій, опублікованих у них - це побутові фотографії «республіки» (вони складають 54,4\% від усіх фотографій чотирьох газет, тобто 667 фото). Сюди зараховані фотографії інфраструктурних об’єктів, обладнання та фотографії благоустрою територій. Також достатньо уваги приділяється масово-культурним подіям так званої Луганської народної республіки (ЛНР) (21,0\% від усіх фотографій чотирьох газет і складає 258 фотографій). На цих фото зображені різного виду культурні події: вистави, виставки, концерти, змагання тощо. Майже половина таких публікацій можна зустріти на сторінках газети «Експрес новини». Фотографії, які присвячені повсякденному життю жителів так званої Луганської народної республіки, складають 8,5\% (105 світлин). Найчастіше на цих світлинах зображені робочі місця, офіси, шкільні класи 3 дітьми, портрети жителів «республіки» та загальні світлини краєвидів та міста. Фотографії з політичними лідерами так званої ЛНР та воєнними діями на іiі території займають 1,9\% та 1,9\% відповідно. Найчастіше такі світлини зустрічаються на сторінках газети «21 століття», а на сторінках «Козачого вісника» такі фотографії відсутні взагалі. Світлини політичних подій так званої ЛНР займають 1,7\%. Портрет I. Плотницького на шпальтах газет 3'являється не часто (1,6 \% від усіх фотографій чотирьох газет). Цікаво, що найбільша кількість таких публікацій на сторінках газет «Антрацитовський вісник» та «21 століття». Слід зазначити, що достатній відсоток фотографій присвячені Антрацитовському лідеру, а саме А. Андрієнку (1,8\% від усіх фотографій чотирьох газет, що складає 22 світлини). Фотографії бойовиків так званих ЛНР / ДНР займають 1,3\%, а фотографій з військовими ВСУ зовсім відсутні. Слід зупинитись на таких світлинах, які відображають історичні події Царської Росії, від усіх фотографій чотирьох газет, що складає 16 світлини. Говорячи про фотографії президентів України та Росії, то фотографії Володимира Путіна складають 0,9\%, а фотографії Петра Порошенка складають 0,4\%. У газетах «Антрацитовський вісник» та «21 століття» такі фото взагалі відсутні.
Також проводився замір цих фотографій. Тому можна зазначити, що найбільшу площу займають публікації щодо інфраструктури Луганської на-

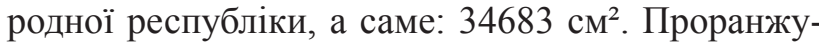
вавши площу фотокарток, отримали: культурних подій - $14900 \mathrm{~cm}^{2}$; світлини бойовиків та бойових подій займають 5385,5 см²; повсякдення мешканців - $4200 \mathrm{~cm}^{2}$; політичних подій - 3255 см$^{2}$; царської Російської Імперії - 1976 см$^{2}$; політичних лідерів Антрациту -880 см$^{2}$; В. Путіна - 637 см²; луганських політичних лідерів - $420 \mathrm{~cm}^{2}$; І. Плотницького - $314 \mathrm{~cm}^{2}$; П. Порошенка $-288 \mathrm{~cm}^{2}$. Цікавим виявилось те, що кількість світлин може бути меншою, а площа цих фотографій більша. Такі фото стосуються В. Путіна, Царської Росії, фотографії бойових подій. До речі, фотожаби використовуються вкрай рідко, їх частіше можна зустріти в Інтернеті.

\section{Висновок.}

Отже, проранжувавши усі фотографії, можна дійти висновку, що більшість уваги приділяється саме побутовій сфері ЛНР та повсякденному життю республіки. Підсумовуючи, можна сказати, що увага приділяється саме фінансовому питанню як так званої ЛНР, так і інших країн (209 публікацій). Отже, фінанси (податки, кредити) так званої Луганської народної республіки становлять - 41 публікація, Україна - 39 статей, РФ - 34 публікацій, США, СС - 21 статей. Вугільна промисловість також займає чільне місце, проте, якщо розглядати так звану ЛНР, то тут мова йде про видобуток та поставки вугілля - 20, а якщо розглядати Україну, то більшість матеріалів присвячені тому, що Україна потерпає від нестачі вугілля та закупає його за дуже високими цінами за кордоном - 9 публікацій. Велике значення приділяється і газовій галузі, так матеріали щодо газового питання присвячені Україні, Росії й ЛНР (8,7,3 публікацій відповідно). Проаналізувавши матеріали газет, можна зазначити, що для Луганської Народної Республіки більш важливим є будівництво (10 публікацій), тобто відновлення будівель різного характеру, які постраждали під час бойових дій. На шпальтах газет дуже часто зустрічаються статті, присвячені відновленню будинків, шкіл, дитячих садків та ін. Можна припустити, що звідси й велика кількість фотографій, присвячених побутовому та повсякденному життю.

\section{БІБІЛІОГРАФІЧНІ ПОСИЛАННЯ}

1. Адорно Т. (1997). Диалектика просвещения. Философские фрагменты / Т. Адорно, М. Хоркхаймер; пер. с англ. М. Кузнецова. - СПб.,1997. - Режим доступа: http://gtmarket.ru/laboratory/basis/5521

2. Батлер Дж. Психика власти: теории субъекции / Дж. Батлера. - Харьков: ХЦГИ, 2002. - 168 с.

3. Бауман 3. Индивидуализированное общество / 3. Бауман. - М.: Логос, 2005. - 390 с.

4. Бергер П. Социальное конструирование реальности / П. Бергер, Т. Лукман. - М., 1995. - 97 с.

5. Бодрийяр Ж. Реквием по масс-медиа / Ж. Бодрийяр // Поэтика и политика. - М., 1999. - С. 193-226 
6. Бурдье П. О телевидении и журналистике / П. Бурдье. - М.: Фонд научных исследований «Прагматика культуры», Институт экспериментальной социологии, 2002. - 160 с.

7. Валлерстайн И. Конец знакомого мира: Социология ХХІ в. / И. Валлерстайн. - М.: Логос, 2003. -355 с.

8. Вебер М. Основные социологические понятия / М. Вебер // Западно-европейская социология XIX-начала XX веков. - М., 1996. - С. 455-491.

9. Грушин Б. А. Эффективность массовой информации и пропоганды: понятия и проблемы измерения / Б. А. Грушин. - М: Политиздат,1987. - 127 с.

10. Карлова В. В. Вплив засобів масової інформації на формування української національної свідомості / В. В. Карлова. - Режим доступу: http://academy.gov.ua/ej/ej6/txts/07kvvunc.htm.

11. Кастельс М. Информационная эпоха: Экономика, общество и культура / М. Кастельс. - М.: ГУ ВШЭ, $2000 .-478$ с. 12. Ксенофонтова И. В. Специфика коммуникации в условиях анонимности: меметика, имиджборды, троллинг / И. В. Ксенофонтова // Интернет и фольклор. Сборник статей. М.: Государственный республиканский центр русского фольклора, 2009. - С. 285-294.

13. Липпман У. Общественное мнение / У. Липпман. - М.: Институт Фонда «Общественное мнение», 2004. - 384 с.

14. Маклюен Г. М. Внешние расширения человека / Г. М. Маклюен. - Москва; Жуковский: КАНОН-пресс, 2003. - 464 с. 15. Мертон Р. Массовая коммуникация, массовые вкусы и организованное массовое действие / Р. Мертон, П. Лазарсфельд. - М.: Аспект-пресс, 2000. - 323 с.

16. Почепцов Г. Г. Информационные войны / Г. Г. Почепцов. - М.: Рефл-бук, 2000. - 576 с.

17. Тоффлер Е. Третя Хвиля // Е. Тоффлер. - Київ: Вид. дім «Всесвіт», 2000. - 480 с.

18. У СБУ заявили, що російські канали застосовують проти телеглядачів заборонений метод «25-го кадр». Режим доступу: http://tsn.ua/politika/u-sbuzayavili-scho-rosiyski-kanali-zastosovuyut-protiteleglyadachiv-25-ykadr-350517.html.

19. Хабермас Ю. Теория коммуникативного действия (фрагменты) / Ю. Хабермас // Вопросы социальной философии. - 2007. - Т. 1 - № 1. - С. 229-245

\section{REFERENCES}

1. Adorno, T., \& Khorkkhaimer, M. (1997). Dialektika prosveshcheniia. Filosofskie fragmenty [The dialectic of enlightenment. Philosophical Fragments]. Saint-Petersburg: Tcentr gumanitarnykh tekhnologii. Retrieved from: http:// gtmarket.ru/laboratory/basis/5521 [in Russian].

2. Batler, Dzh. (2002). Psikhika vlasti: teorii subektcii [Psychic power: the theory of subjectivity]. Kharkov: KTGI [in Russian].

3. Bauman, Z. (2005). Individualizirovannoe obshchestvo [Individualized society]. Moscow: Logos [in Russian].

4. Berger, P., \& Lukman, T. (1995). Sotcialnoe konstruirovanie realnosti [Social construction of reality]. Moscow: Nauka [in Russian].

5. Bodriiar, Zh. (1999). Rekviem po mass-media [Requiem for the Media]. Poetika i politika (pp. 193-226). Moscow [in Russian].

6. Burde, P. (2002). O televidenii i zhurnalistike [About Television and Journalism]. Moscow: Foundation for Scientific Research «Pragmatics of Culture», Institute of Experimental Sociology [in Russian].

7. Vallerstain, I. (2003). Konetc znakomogo mira [End of the familiar world: Sociology of the XXI century]. Moscow [in Russian].

8. Veber, M. (1996). Osnovnye sotciologicheskie poniatiia [Basic sociological concepts]. Western European sociology of the nineteenth and early twentieth centuries. Moscow [in Russian].

9. Ghrushyn, B.A. (1987). Efektyvnistj masovoji informaciji i propaghandy: ponjattja ta problemy vymiru [The effectiveness of mass information and propaganda: the concepts and problems of measurement]. Moscow: Politizdat [in Russian].

10. Karlova, V.V. Vplyv zasobiv masovoji informaciji na formuvannja ukrajinsjkoji nacionaljnoji svidomosti [Influence of the mass media on the formation of Ukrainian national consciousness]. Retrieved from: http://academy.gov.ua/ej/ej6/ txts/07kvvunc.htm [in Ukrainian].

11. Kastels, M. (2000). Informatcionnaia epokha: Ekonomika, obshchestvo i kultura [Information Age: Economics, Society and Culture]. Moscow: State University Higher School of Economics [in Russian].

12. Ksenofontova, I.V. (2009). Specyfika komunikaciji v umovakh anonimnosti: memetyka, imidzhbordy, troling [Specificity of communication in the conditions of anonymity: memetics, image boards, trolling]. Internet $i$ foljklor. Zbirnyk statej. Moscow: State Republican Center of Russian Folklore [in Russian].

13. Lippman, U. (2004). Ghromadsjka dumka [Public opinion]. Moscow: Instytut Fondu «Ghromadsjka dumka» [in Russian].

14. Makliuen, G.M. (2003). Vneshnie rasshireniia cheloveka [External extensions of man]. Moscow; Zhukovskii: KANON - press [in Russian].

15. Merton, R., \& Lazarsfeld, P. (2000). Massovaia kommunikatciia, massovye vkusy i organizovannoe massovoe deistvie [Mass communication, mass tastes and organized mass action]. Moscow: Aspekt-press [in Russian].

16. Pocheptcov, G.G. (2000). Informatcionnye voiny [Information warfare]. Moscow: Refl-buk [in Russian]. 
17. Toffler, E. (2000). Tretja Khvylja [Third Wave]. Kyiv: Vyd. dim «Vsesvit» [in Ukrainian].

18. U SBU zajavyly, shho rosijsjki kanaly zastosovujutj proty teleghljadachiv zaboronenyj metot "25-gho kadr» [The SBU said that Russian channels use a «25th frame» method prohibited against viewers]. Retrieved from: http://tsn.ua/ politika/u-sbuzayavili-scho-rosiyski-kanali-zastosovuyut-protiteleglyadachiv-25-y-kadr-350517.html [in Ukrainian].

19. Habermas, Ju. (2007). Teoriya kommunikativnogo deystviya (fragmenty) [Theory of communicative action (fragments)]. Questions of social philosophy, Vol. 1 (1) [in Russian].

\section{Котеленець Катерина Михайлівна}

Кандидат соціологічних наук, доцент кафедри філософії та соціології Луганський національний університет імені Тараса Шевченка 92703, м. Старобільськ, пл. Гоголя, 1

\section{Kotelenets Kateryna}

$\mathrm{PhD}$ of Sociology, Assoc. Prof., Department of Philosophy and Sociology Lugansk Taras Shevchenko National University

1 Gogol Square, 92703, Starobilsk, Ukraine

ORCID: 0000-0002-1921-0572＿Email: lnu.katemix@gmail.com

Цитування: Котеленець К. М. Візуалізація суспільного життя окупованої території Луганської області у друкованих засобах масової інформації / К. М. Котеленець // Науково-теоретичний альманах «Грані». - 2018. - T. 21. - № 3. - C. 12-17.

Citation: Kotelenets, K.M. (2018). Vizualizatsiia suspilnoho zhyttia okupovanoi terytorii Luhanskoi oblasti $\mathrm{u}$ drukovanykh zasobakh masovoi informatsii [Visualization of the social life of the occupied territory of the Lugansk region in the print media]. Scientific and theoretical almanac "Grani», 21(3), 12-17. 